\title{
PENYELENGGARAAN PENDIDIKAN PADA MADRASAH ALIYAH NEGERI II DAN PERSEPSI MASYARAKAT DI PALU SULAWESI TENGAH *
}

\author{
Oleh : M.Arsyad MG.**
}

\begin{abstract}
I
Penguasaan Ilmu Pengetahuan dan Teknologi akan mempengaruhi keberhasilan membangun masyarakat maju dan mandiri. Pembangunan Ilmu Pengetahuan dan Teknologi diarahkan agar pemanfaatan, pengembangan, dan penguasaannya dapat mempercepat proses pembaharuan, meningkatkan produktivitas dan efesiensi, memperluas lapangan kerja meningkatkan kesejahteraan rakyat (GBHN : 19.93).
\end{abstract}

Untuk menggapai semua itu, ditempuh jalan yang paling bijak adalah lewat pendidikan. Pendidikan merupakan tanggung jawab bersama antara keluarga, masyarakat dan pemerintah, termasuk juga dalam hal biaya penyelenggaraan pendidikan. Jenjang pendidikan yang termasuk jalur pendidikan sekolah terdiri atas pendidikan dasar, pendidikan menengah, dan pendidikan tinggi. Pendidikan menengah terdiri atas pendidikan menengah umum, pendidikan menengah kejuruan, pendidikan menengah luar biasa, pendidikan menengah kedinasan," dan pendidikan menengah keagamaan. Pendidikan menengah umum adalah pendidikan pada jenjang

\footnotetext{
* Resume hasil penelitian ini diseminarkan pada Seminar Agama dan Kemasyarakatan pada tanggal 30 Nopember 1995 di Ujungpandang.

* Staf Peneliti Balai Penelitian Lektur Keagamaan.
}

pendidikan menengah yang mengutamakan perluasan pengetahuan dan peningkatan keterampilan siswa. Sekolah Menengah Umum (SMU) dan SMU berciri khas agama Islam atau Madrasah Aliyah (MA), yang mengutamakan penyiapan siswa untuk melanjutkan pendidikan pada jenjang pendidikan tinggi dengan pengkhususan yang diwujudkan pada tingkat-tingkat akhir masa pendidikan (UU No. 2 : 1989 dan PP No. $29:$ 1990).

Madrasah Aliyah (MA) adalah SMU yang berciri khas agama Islam yang diselenggarakan oleh Departemen Agama (SK Mendikbud Nomor 0489/U/1993 Pasal 1 butir 6).

Persepsi pada hakekatnya adalah proses kognitif oleh setiap orang di dalam menekuni informasi tentang lingkungannya.baik lewat penglihatan, pendengaran, penghayatan, perasaan dan penciuman (Thoha, 1983 : 138).

Kunci untuk memahami persepsi menurut Thoha, adalah terletak pada pengenalan, bahwa persepsi itu merupakan suatu penafsiran yang unik terhadap situasi (stimulasi), bukannya suatu pencatatan yang benar terhadap situasi tersebut (1983 : 138).

Dari rangkaian hal-hal tersebut di atas, ada satu hal yang menarik untuk diamati, mengenai pelaksanaan proses belajar mengajar pada MA, dimana pada tahun ajaran yang sedang berjalan 
(95/96) ini ada 2 kurikulum yang diberlakukan, yakni : Kurikulum MA 84 dan Kurikulum MA 94.

Pada kondisi yang demikian memberi peluang akan lahirnya kemenonjolan-kemenonjolan yang berkaitan erat dengan kelembagaan, kurikulum itu sendiri, siswa sebagai peserta didik, guru dan tenaga kependidikan lainnya, sarana dan prasarana, administrasi, dan keadaan umum pada sekolah yang menjadi sasaran penelitian.

Masalah utama dalam penelitian ini ialah : seperti apa wujud kemenonjolan tersebut dalam penyelenggaraan pendidikan pada MA, dan persepsi masyarakat dalam penyelenggaraan pendidikan pada MA.

Berdasarkan masalah utama ini, dirumuskan tujuan penelitian, yaitu : Untuk menelusuri dan mengungkapkan wujud kemenonjolan apa saja dalam penyelenggaraan pendidikan pada MA dan pengaruhnya terhadap persepsi masyarakat.

\section{II}

Penelitian ini dilakukan di Kelurahan Besusu Kecamatan Palu Timur dengan dasar pertimbangan, di wilayah ini terdapat beberapa Sekolah Menengah Umum dan Madrasah Aliyah yang memiliki sejumlah prestasi.

Populasi penelitian adalah Sekolah Menengah Umum dan Kepala Keluarga yang berdomisili dalam wilayah Kelurahan Besusu. Pertimbangannya adalah : Di sekolah menengah akan dilakukan pengamatan tentang penyelenggaraan pendidikan, sementara lewat Kepala Keluarga akan dijaring data persepsi masyarakat tentang penyelenggaraan pendidikan.

Sampel ditarik secara perposive, yaitu Madrasah Aliyah Negeri (MAN) II, dan 100 orang Kepala Keluarga $(\mathrm{KK})$ yang terdiri dari $50 \%$ bertempat tinggal dekat (radius $0-1 \mathrm{Km}$ ) dari sekolah yang diamati, dan $50 \%$ lagi bertempat tinggal jauh (radius 1 - 2 $\mathrm{Km}$ ) dari sekolah yang diamati (MAN II Palu).

Dalam pengumpulan data, digunakan cara : pertama di sekolah yang terpilih sebagai sampel dilakukan pengamatan atas penyelenggaraan pendidikan, dari situ diperoleh hal-hal yang menarik untuk dipertanyakan; kedua wawancara bebas dengan Kepala Sekolah, Wakil Kepala Sekolah, Tenaga Pendidik, Tenaga Pembimbing atau Guru BP, Tenaga Administrasi, peserta didik/siswa, Tokoh Pendidik baik yang berada di Lingkungan Departemen Agama, maupun yang berada di lingkungan Departemen Pendidikan dan Kebudayaan serta yang berada pada lingkungan pemerintahan; ketiga pengedaran angket kepada KK yang terpilih sebagai sampel.

Pengolahan data dilakukan dengan cara : data yang sifatnya kualitatif, terutama dari hasil pengamatan dan wawancara bebas diolah secara kualitatif; sedang data yang sifatnya kuantitatif (dijaring dari angket) diolah secara kuantitatif disajikan dalam tabel frekuensi khususnya mengenai prestasi siswa, sekolah, sarana pendidikan, dan out put/lulusan sekolah, yang disesuaikan dengan jenis data dan tujuan penelitian.

Demikian pula analisis, data yang sifatnya kualitatif dilakukan analisis kontekstual dan deskriptif kualitatif, sementara data kuantitatif digunakan sebagai data penunjang. 
III

Penyelenggaraan pendidikan pada MAN II Palu. Dalam penyelenggaraan pendidikan ini, yang ditonjolkan adalah 4 hal, yang meliputi : dampak yang ditimbulkan kurikulum MA 94, laboratorium dan perpustakaan sekolah, prestasi siswa, hambatan dan penanggulangannya.

Dampak yang ditimbulkan kurikulum MA 94.

Pada prinsipnya perbedaan-perbedaan yang terdapat pada pembagian mata pelajaran antara kurikulum 94 dengan kurikulum 84, adalah penyesuaian istilah dalam pengelompokan bidang studi dalam kaitannya pengembangan status MA menjadi SMU yang berciri khas agama Islam.

Prinsip perbedaan yang terdaapt dalam mata pelajaran Pendidikan Agama Islam adalah berwujud pengurangan 2 GBPP yakni : Aqidah Akhlak dan Bahasa Arab masing-masing 2 jam pelajaran a' 45 menit/ 1 jam pelajaran, $\cdot$ total $4 \times 45$ menit $=180$ menit. Khusus Aqidah Akhlak terjadi tidak diajarkan lagi pada Kelas III untuk semua program umum. Adapun Bahasa Arab berubah dari status intra kurikuler sebanyak 5 jam pelajaran menjadi ekstra kurikuler sebanyak 2 jam pelajaran maka terjadi pengurangan 3 jam pelajaran pada Kelas I, II, dan III untuk semua program umum. Sementara Bahasa Arab pada SMAN I dan IV Palu memilih sebagai pilihan dalam mata pelajaran bahasa asing lainnya sebanyak 5 jam pelajaran, dalam konteks ini anak/siswa SMA lebih berpeluang banyak menguasai bahasa Arab ketimbang anak/siswa MA.
Laboratorium bahasa MAN II ini adalah laboratorium kedua di Palu sesudah laboratorium bahasa Universitas Tadulako (UNTAD). Laboratorium ini memiliki 40 unit Walkam, sebuah Tape Corde "Panasonic", dan 1 set kaset pelajaran Bahasa Inggris "Hilman" yang berisi keterampilan membaca, menyimak, berbicara, dan menulis dalam bahasa Inggris. Total biaya sebanyak 4,5 juta rupiah semuanya bersumber dari dana BP3. Laboratorium ini dibimbing oleh seorang tenaga pembimbing yakni Drs.Surono bernip 15. Surono adalah guru tetap Bahasa Inggris dan merekalah dengan keterampilannya merakit sendiri alat-alat electro yang digunakan di laboratorium bahasa ini.

Sementara pada laboratorium IPA beda halnya dengan laboratorium bahasa. Alat dan bahan praktikum IPA adalah merupakan faktor penunjang yang menentukan pencapaian target dalam proses belajar mengajar dalam bidang studi Fisika, Biologi, dan Kimia. Kenyataannya demonstrasi atau praktikum di laboratorium ini sering tidak tuntas dalam membahas pokok-pokok bahasan dalam bidang studi seperti tersebut di atas, karena alat dan bahan tidak ada, sehingga hanya dilakukan pengamatan lewat gambar dalam GBPP tersebut.

Yang ditemui di perpustakaan sekolah ketika dilakukan pengaamtan adalah : sebuah ruangan khusus, di dalam lemari dan rak terdapat 66 judul buku yang berasal dari berbagai kalangan, koleksi tersebut didominasi oleh buku-buku warisan PGAN, sehingga banyak sudah yang kurang diminati siswa MA. Tenaga pengelola berlatar belakang pendidikan SI yang berstatus honorer selama 2 bulan terakhir, kelemahan dalam pelayanan karena tidak terjalinnya 
hubungan teknis fungsional antara tenaga pembina dengan pengelola, acuan yang ada Dewey Decimal Classification sementara dipelajari, jadwal pelayanan tidak dibuat.

Prestasi peserta didik/siswa. Hasil EBTANAS Sendiri untuk Tahun Ajaran 94/95 $90 \%$ LULUS, terdiri dari program A. $5=14$ orang, A. $3=23$ orang, A. $2=29$ orang, dan A. $1=56$ orang. Sedangkan hasil EBTANAS Bersama untuk tahun ajaran yang sama LULUS $100 \%$ terdiri dari program a.5 $=14$ orang, A. $3=23$ orang, dan A. 2 $=29$ orang. Prestasi juara dalam berbagai jenis lomba (ekstra kurikuler) yang diikuti oleh sekolah dalam tahun ajaran 94/95, yang ditandai dengan Piala Trophy, Piagam, dan Tabanas yang ditata dengan baik di ruang Kepala Sekolah.

Hambatan yang paling menonjol dalam penyelenggaraan pendidikan MAN II Palu, adalah berkurangnya penyajian mata pelajaran Aqidah Akhlak dan pengurangan jam pelajaran dan perubahan status dalam penyajian Bahasa Arab, serta pada Tahun Ajaran 95/96 yang akan datang seorang: Guru Bahasa Arab akan mengakhiri masa baktinya (Pensiun); Kurangnya tenaga Guru Tetap untuk mata pelajaran Eksakta : Kimia, Fisika, Biologi, Ekonomi, Bahasa Inggris, dan Bahasa Jerman; Alat dan bahan praktikum IPA lebih banyak tidak memenuhi target; koleksi perpustakaan tidak sesuai kebutuhan GBPP MA.

Penanggulangan kekurangan jam pelajaran dilakukan dengan pengayaan, kelebihan jam mengajar tersebut dibiayai oleh BP3 sebanyak Rp 2.500,-/jam pelajaran. Kekurangan Guru Tetap untuk bidang studi tertentu dilakukan pengangkatan tenaga Guru Honor yang dibiayai oleh BP3 sebanyak Rp 2.500,/jam pelajaran. Penanggulangan kurangnya alat dan bahan praktikum IPA dilakukan pengamatan gambar dan menggunakan bahan dan alat yang ada. Pengadaan koleksi perpustakaan yang dibutuhkan dilakukan permohonan kepada Bidang Pembinaan Kelembagaan Agama Islam seperti Buku Hadits Ilmu Hadits Jilid I dan II, Buku Qur'an Hadits Jilid I dan II, Buku Tafsir Ilmu Tafsir Jilid I dan II, masing-masing 21 eksamplar.

\section{IV}

Dari 100 orang responden mempersepsikan secara bervariasi atas prestasi siswa tentang hasil pembinaan PRAMUKA $85 \%$ yang menyatakan baik, dan hanya $2 \%$ yang menyatakan tidak baik; hasil pembinaan Palang Merah $54 \%$ yang menyatakan baik, dan hanya $1 \%$ yang menyatakan sangat tidak baik; hasil cawu akhir $53 \%$ yang menyatakan baik, dan hanya $1 \%$ yang menyatakan sangat tidak baik; sementara hasil pembinaan olahraga, seni dan keterampilan $45 \%$ yang menyatakan sangat baik, dan hanya $6 \%$ yang menyatakan netral.

Dari angka-angka yang ekstrim positif di atas bermakna persepsi masyarakat atas prestasi siswa dalam wujud hasil pembinaan kepramukaan, kepalangmerahan, keolahragaan - kesenian dan keterampilan, serta prestasi cawu akhir, jauh lebih banyak yang menilai baik ketimbang yang sangat tidak baik.

Dari 100 orang responden mempersepsikan secara bervariasi atas prestasi sekolah tentang : hasil pembinaan PRAMUKA $86 \%$ yang menyatakan baik, hanya $1 \%$ yang menyatakan tidak 
baik; hasil lomba karya tulis $63 \%$ yang menyatakan baik, hanya $2 \%$ yang menyatakan sangat tidak baik; hasil pembinaan Palang Merah $52 \%$ yang menyatakan baik, hanya $2 \%$ yang menyatakan sangat tidak baik; sementara hasil pembinaan olahraga, seni, dan keterampilan $49 \%$ yang menyatakan sangat baik, dan $8 \%$ yang menyatakan baik.

Dari angka-angka yang ekstrim positif di atas bermakna persepsi masyarakat atas prestasi sekolah dalam wujud hasil pembinaan kepramukaan, hasil pembinaan karya tulis, hasil pembinaan kepalangmerahan, dan hasil pembinaan keolahragaari, kesenian dan keterampilan, jauh lebih banyak yang menilai baik ketimbang yang sangat tidak baik.

Dari $100 \%$ orang responden mempersepsikan secara bervariasi atas sarana pendidikan tentang : gedung sekolah $85 \%$ yang menyatakan baik, dan hanya $1 \%$ yang menyatakan sangat tidak baik; olahraga, seni dan keterampilan $72 \%$ yang menyatakan baik, dan hanya $2 \%$ yang menyatakan sangat tidak baik; laboratorium sekolah $52 \%$ yang menyatakan sangat baik, hanya $3 \%$ yang menyatakan sangat tidak baik; perpustakaan sekolah $40 \%$ yang menyatakan baik, hanya $7 \%$ yang menyatakan sangat tidak baik.

Dari angka ekstrim positif di atas bermakna persepsi masyarakat atas sarana pendidikan dalam wujud gedung sekolah, sarana keolahragaan, kesenian dan keterampilan, sarana laboratorium Bahasa dan IPA, dan sarana kepustakaan sekolah, jauh lebih banyak yang menilai baik ketimbang yang sangat tidak baik.
Dari 100 responden mempersepsikan secara bervariasi atas output/lulusan sekolah tentang : lebih banyak bekerja pada lingkung-an Departemen Agama $44 \%$ yang menyatakan baik, hanya $4 \%$ yang menyatakan sangat tidak baik; lebih banyak melanjutkan ke Perguruan Tinggi Agama $43 \%$ yang menyatakan baik, hanya $4 \%$ yang menyatakan sangat tidak baik; lebih banyak melanjutkan ke Perguruan Tinggi Umum 39 \% yang menyatakan baik, hanya $2 \%$ yang menyatakan sangat tidak baik; sementara lebih banyak menganggur $36 \%$ yang menyatakan tidak baik, hanya $1 \%$ yang menyatakan sangat baik.

Dari angka-angka ekstrim positif di atas bermakna persepsi masyarakat atas out put/lulusan sekolah dalam wujud lebih banyak bekerja pada Departemen Agama, lebih banyak melanjutkan ke Perguruan Tinggi Agama, lebih banyak melanjutkan ke Perguruan Tinggi Umum, jauh lebih banyak yang menilai baik ketimbang yang sangat tidak baik; sementara lebih banyak yang menyatakan bahwa menganggur itu tidak baik.

Perbandingan score persepsi masyarakat antara yang bertempat tinggal dekat (radius 0 - $1 \mathrm{Km}$ ) dengan yang bertempat tinggal jauh (radius $1-2 \mathrm{Km}$ ) dari sekolah yang diamati :

Lebih besar score (488) dari 50 orang responden yang bertempat tinggal jauh dari sekolah mempersepsikan prestasi siswa dengan nilai baik, ketimbang score (476) dari 50 orang responden yang bertempat tinggal dekat. Selisih score 12 bermakna karena mereka menilai baik prestasi siswa dalam wujud dari hasil pembinaan kepramukaan dan kepalangmerahan. 
Lebih besar score (444) dari 50 orang responden yang bertempat tinggal jauh dari sekolah mempersepsikan prestasi sekolah dengan nilai baik, ketimbang score (392) dari 50 orang responden yang bertempat tinggal dekat. Selisih score 52 bermakna karena mereka menilai baik prestasi sekolah dalam wujud dari hasil pembinaan kepramukaan dan kepalangmerahan.

Lebih besar score (520) dari 50 orang responden yang bertempat tinggal dekat dari sekolah mempersepsikan sarana pendidikan dengan nilai baik, ketimbang score (344) dari 50 orang responden yang bertempat tinggal jauh. Selisih score 176 bermakna karena mereka menilai baik sarana pendidikan dalam wujud sarana gedung sekolah dan sarana perpustakaan.

Lebih besarscore (368) dari 50 orang responden yang bertempat tinggal dekat dari sekolah mempersepsikan out put/lulusan sekolah dengan nilai baik, ketimbang score (212) dari 50 orang responden yang bertempat tinggal jauh. Selisih score 156 bermakna karena mereka menilai baik out put/lulusan sekolah dalam wujud lebih banyak melanjutkan ke Perguruan Tinggi Agama dan Umum ketimbang yang bekerja.

Persepsi responden/masyarakat yang variatif sebagaimana tersebut di atas, merupakan suatu proses yang aktif dimana yang memegang peranan bahwa bukan hanya informasi penyelenggaraan yang mereka terima, tetapi juga diri responden/masyarakat tersebut secara total, pengalaman, sikap-sikap relevan, dan motivasinya, terhadap penyelenggaraan pendidikan pada MAN II Palu.
Disini terlihat, bahwa proses persepsi meliputi suatu interaksi yang sulit dari kegiatan seleksi, penyusunan, dan penafsiran. Selama proses, mulai dengan penginderaan sampai dengan lahirnya persepsi atau penafsiran, terdapat banyak pengaruh-pengaruh. Selama penginderaan, kemampuan pisik untuk mendengar dan melihat dapat menambah atau mengurangi nilai penyelenggaraan pendidikan pada MAN II Palu senyatanya.

Penafsiran merupakan masa proses persepsi yang amat penting. Proses penafsiran ini banyak dipengaruhi oleh pengalaman, motivasi, dan kepribadian responden, yang berbeda antara satu individu dengan individu lainnya. Disinilah letak sumber perbedaah utama dari persepsi (Thoha 1983 : 142).

$$
\text { V }
$$

Penyelenggaraan pendidikan pada MAN II Palu dilihat dari kelembagaan, kurikulum, siswa sebagai peserta didik, guru dan tenaga kependidikan lainnya, sarana dan prasarana, administrasi, dan keadaan umum sekolah, pada umumnya telah dilakukan. Sementara wujud kemenonjolan yang terungkap disini adalah pada jalur kurikulum, prestasi baik siswa maupun sekolah, baik dalam intra kurikuler maupun ekstra kurikuler ternyata berjalan baik.

Dari penyelenggaraan pendidikan yang ternyata berjalan baik sesuai potensi yang ada sampai pengaruhnya terlihat pada warna persepsi responden/masyarakat seputarnya jauh lebih banyak yang menyatakan baik ketimbang yang menyatakan tidak baik. 


\section{DAFTAR KEPUSTAKAAN}

Clifford Geertz, Abangan. Santri Priyai 1986 Dalam Masvarakat Jawa Cet. Ill, Pustaka Jaya, Jakarta.

Fredrik Barth.Kelompok Etnikd dan 1988 Batasannva. Universitas Indo nesia, Ul-Press, Jakarta.

Georges Balandir, Antropologi Politik, 1986 CV. 1983 Rajawali, Jakarta.

Ibrahim Erlangga, Swadaya, Senantiasa 1983 Kata Kunci, dalam Swasono (1983).

J.Dixon, Wilfrid dan J.Massey,Frank Jr, 1979 Pengantar Analisis Statistik, Bandung Gajah Mada University Press.

Ketetapan MPR 1993 dan GBHN Tahun 1993, Beringin Jaya, Semarang.

Koentjaraningrat, Pengantar Ilmu Antro1980 pologi, Jakarta, Aksara Baru.

Kebudayaan Mentalitas 1984 dan Pembangunan, Cet. II PT. Gramedia Jakarta. 1985 dalam Penelitian Masvarakat, PT. Gramedia, Jakarta.

* _. Manusia dan Kebuda1985 yaan di Indonesia, Jembatan, Jakarta.

Masvarakat Desa dilndo1984 nesia, Universitas Indonesia, Jakarta.

Muljanto Sumardi, Penelitian Agama, 1977 Masalah dan Pemikiran, Jakarta, Sinar Harapan, Cetakan I.
Mar'at, Sikap Manusia, Perubahan dan 1982 Pengukurannya, Jakarta, Ghhalia Indonesia, Cetakan Pertama.

Poerwadarminta, W.J.S., Kamus Umum 1976 Bahasa Indonesia, Jakarta, PN. Balai Pustaka.

Pringgodigdo, A. G. dan Hasan 1977 Shadily, Ensiklopedi Umum, Jakarta, Yayasan Kansius.

Parsudi Suparlan, Pengetahuan Budaya, 1981 Iimu-ilmu Sosial dan Pengkaiian Masalah-masalah Agama, Proyek Penelitian Keagamaan Badaan Litbang Agama, Jakarta.

- Dalam H. Zaini 1986 Ahmadsyis, Dialog No. 21, Badan Penelitian dan Pengembang Agama, Jakarta.

Sadli, Saparinah, Persepsi Sosial Me1977 ngenai Prilaku Menyimpang, Jakarta, Bulan Bintang.

Thoha, Miftah, Prilaku Organisasi 1983 Konsep Dasar dan Aplikasinva, Jakarta, Rajawali.

Wijaja, A.W., Manusia Indonesia, In1986 dividu, Keluarga, dan Masvarakat, Akademika, Pres Sindo, Jakarta.

Zainal Arifin Abbas, Perkembangan 1984 Pemikiran Terhadap Agama, Cet. II, Pustaka Al-Husna, Jakarta. 